\title{
GAMBARAN TEKANAN DARAH PADA PEMAIN MUSIK DI SEKOLAH MUSIK TOMS YAMAHA MUSIC SCHOOL MANADO
}

\author{
${ }^{1}$ Hermin Garusim \\ ${ }^{2}$ Joice N. A. Engka \\ ${ }^{2}$ Siantan Supit
}

\author{
${ }^{1}$ Kandidat Skripsi Fakultas Kedokteran Universitas Sam Ratulangi Manado \\ ${ }^{2}$ Bagian Fisiologi Fakultas Kedokteran Universitas Sam Ratulangi Manado \\ Email: Hermingadish_08@yahoo.co.id
}

\begin{abstract}
Blood pressureand pulse rateis very important in the health sectorin general, and particularly in the field of medicine, since the blood pressure and pulse rateis a factor that can be used as an indicator to assessa person's cardiovascular system. Blood pressure is the force used by the blood against the walls of blood vessels (arteries). Blood pressure is a vital sign in the human body. Numerous studies have shown an relationship between changes of blood pressure with pounding music that are to heard or playing a musical instrument. Physiologically increases and decreasesin blood pressurecan becaused bya particulargenre. As well as the increase and decrease in blood pressure both before and after playing music in fluenced by physical activity while playing certain musical instruments. For example, a drum player, his blood pressure willincrease two-fold in time afterplayingthe music, and theviolin decreased time after playing music. The purpose of this study, was to determine what kind of instrument music that can increase and decrease blood pressure. The type of research is observational with cross sectional study. The variable in this study is a music player and high blood pressure. The subjects was students in the school musical TOM's Yamaha Music School as many as 40 people who have met the criteria for inclusion are aged 10-35 years consisted of men and women, physically and mentally healthy, not suffering from hypertension and signed the informed consent. Measurement of blood pressure used tensimeter aneroid ABN spectrum and Littmann stethoscope. Before playing the music, the averages blood pressure with result that optimal is $106 / 74 \mathrm{mmHg}$, the averages blood pressure with result that normal is $121 / 80 \mathrm{mmHg}$, the averages blood pressure with result that high normal is $130 / 90 \mathrm{mmHg}$, and the averages blood pressure with result that mild hypertension is $140 / 92 \mathrm{mmHg}$. Based on this research, it was found there are difference in a blood pressure before and after playing music. The normal blood pressure before playing music and will increase or decrease in time after playing the music.
\end{abstract}

Keywords: Blood pressure, Music.

Abstrak: Tekanan darah dan denyut nadi merupakan hal yang sangat penting dalam bidang kesehatan pada umumnya dan khususnya di bidang Kedokteran, karena tekanan darah maupun denyut nadi merupakan faktor yang dapat dipakai sebagai indikator untuk menilai sistem kardiovaskuler seseorang. Tekanan darah adalah tenaga yang di gunakan oleh darah terhadap diding pembuluh darah (arteri). Tekanan darah merupakan salah satu tanda vital di dalam tubuh manusia. Sejumlah penelitian menunjukkan adanya keterkaitan antara perubahan tekanan darah dengan dentuman musik baik yang hanya didengarkan maupun pada saat memainkan alat musik. Secara fisiologis peningkatan dan penurunan tekanan darah dapat diakibatkan oleh aliran musik tertentu. Serta Peningkatan dan penurunan tekanan darah pada saat sebelum dan sesudah bermain musik dipengaruhi oleh aktifitas fisik saat memainkan alat musik tertentu. Misalnya pemain musik drum, tekanan darahnya akan meningkat dua kali lipat pada saat sesudah bermain musik, dan violin (biola) menurun saat sesudah bermain musik.Tujuan dari 
penelitian ini adalah untuk mengetahui jenis alat musik apa yang dapat meningkatkan dan menurunkan tekanan darah. Adapun jenis penelitian ini adalah observasional dengan rancangan cross sectional study. Adapun variable pada penelitian ini adalah pemain musik dan tekanan darah. Subjek penelitian ini adalah siswa-siswi di sekolah musik TOM's Yamaha Music school yaitu sebanyak 40 orang yang telah memenuhi criteria inklusi yaitu berumur 10-35 tahun terdiri atas pria dan wanita, sehat jasmani dan rohani, tidak menderita hipertensi dan menandatangani informed consent. Pengukuran tekanan darah menggunakan tensimeter aneroid ABN spectrum dan stetoskop Littman. Sebelum bermain musik hasil didapatkan tekanan darah optimal dengan rata-rata tekanan darah 106/74mmHg, tekanan darah normal dengan rata-rata 121/80mmHg, tekanan darah normal tinggi 130/90 $\mathrm{mmHg}$, dan tekanan darah dengan hipertensi ringan rata-rata 140/92mmHg. Berdasarkan penelitian yang telah dilakukan, didapatkan adanya perbedaan tekanan darah yang dilakukan saat sebelum dan sesudah bermain musik. Tekanan darah normal pada saat sebelum bermain musik dan akan meningkat atau menurun pada saat sesudah bermain musik.

Kata kunci: tekanan darah, musik.

Tekanan darah dan denyut nadi merupakan hal yang sangat penting dalam bidang kesehatan pada umumnya dan khususnya di bidang Kedokteran, karena tekanan darah maupundenyut nadi merupakan faktor yang dapat dipakai sebagai indikator untuk menilai sistem kardiovaskuler seseorang. Tekanan darah adalah tenaga yang di gunakan oleh darah terhadap diding pembuluh darah (arteri). Tekanan ini harus seimbang, yaitu cukup untuk menghasilkan daya dorong terhadap darah dan tidak boleh terlalu berlebihan (tinggi) yang dapat menimbulkan beban kerja tambahan bagi jantung. ${ }^{1,2,3}$

Tekanan darah terdiri dari sistole dan diastole.Tekanan sistole menunjukkan tekanan saat jantung berkontraksi dan tekanan diastole menunjukkan tekanan saat jantung relaksasi. ${ }^{2}$ Peningkatan atau penurunan tekanan darah akan mempengaruhi homeostasis di dalam tubuh. Secara umum, faktor yang dapat mempengaruhi tekanan darah dalam tubuh kita adalah curah jantung dan tahanan perifer, hormone, umur, jenis kelamin, keturunan, ras, kebiasaan buruk (merokok, konsumsi alkohol dan garam berlebihan, faktor lingkungan maupun sosial. ${ }^{4,5}$

Sejumlah penelitian yang menunjukkan keterkaitan antara perubahan tekanan darah dengan dentuman music baik yang di dengarkan maupun dimainkan oleh seseorang. Peningkatan tekanan darah merupakan suatu bentuk perubahan fisiologis yang dapat diakibatkan oleh aliran musik tertentu. Suatu riset menunjukkan bahwa aliran musik yang dentumannya keras, kencang,dan cepat seperti musik rock, disko, jazz, heavy metal, punk, rap, hip hop dapat menggugah sistem saraf, menggugah nafsu, mempercepat debar jantung dan menegangkan pembuluh darah, meningkatkan pernapasan, membuat denyut nadi makin cepat, hingga pada akhirnya terjadi peningkatan tekanan darah. ${ }^{6-9}$

Berdasarkan uraian di atas, penulis tertarik untuk mengetahui bagaimana pengaruh dari dentuman musik drum terhadap tekanan darah.

\section{METODE PENELITIAN}

Jenis penelitian yang digunakan bersifat observasional, dengan rancangan Cross Sectional Study (studi potong lintang). Dimana pengukuran hanya dilakukan satu kali pada satu populasi di suatu tempat atau daerah. Waktu penelitian dilakukan pada bulan November 2012 dan tempat penelitiannya dilakukan di sekolah musik TOM'S Yamaha music school jl. Samrat no. 159 Manado. Populasi yang digunakan dalam penelitian ini adalah semua pemain musik di sekolah musik TOM's Yamaha music school manado. Sedangkan sampel adalah bagian dari populasi, dalam penelitian ini berjumlah 50 orang yang memenuhi criteria inklusi, yaitu terdaftar sebagai siswa dari sekolah music TOM's Yamaha music school, usia berkisar antara 10-35 tahun, sehat jasmani rohani, tidak memiliki riwayat menderita penyakit 
hipertensi, dan bersedia ikut serta dalam penelitian ini serta menandatangani informed consent. Dalam hal ini jenis variable yang diambil ada 2 macam, yaitu variable bebas (independent) dan variabel terikat (dependent). Variabel bebasnya (independent) adalah Pemain music dan variable terikat (dependent) adalah Tekanan Darah. Data yang dikumpulkan di lapangan berjumlah 40 orang dan semua di ambil darilokasi yang sama. Dalam penelitian ini, subjek yang diteliti sebanyak 40 orang. Sebelum melakukan pengukuran pasien di istirahatkan terlebih dahulu selama 5 menit. Hasil penelitian ini di sajikan dalam bentuk Tabel sebagai berikut:

Tabel 1. Distribusi frekuensi berdasarkan jenis kelamin

\begin{tabular}{lllll}
\hline Jenis & & & \multicolumn{2}{c}{ Rerata TD (mmHg) } \\
\cline { 4 - 5 } Kelamin & n & \% & Sebelum & Sesudah \\
\hline Laki-laki & 25 & 62.5 & $118 / 76$ & $123 / 80$ \\
Perempuan & 15 & 37.5 & $114 / 73$ & $116 / 73$ \\
\hline Total & 40 & 100 & & \\
\hline
\end{tabular}

Pada Tabel 1 dapat dilihat bahwa jumlah sampel terbanyak yang ikut serta dalam penelitian ini adalah laki-laki dengan jumlah 25 orang atau sekitar $62.5 \%$ di bandingkan dengan perempuan yang berjumlah 15 orang atau sekitar $37.5 \%$.
Pada Tabel 2 dapat di lihat pada jumlah sampel yang terbanyak adalah berumur 1620 tahun yaitu 11 orang laki-laki dan 5 orang perempuan atau sekitar 27,5\% untuk laki-laki dan $12,5 \%$ perempuan $12,5 \%$. Sedangkan jumlah sampel yang sedikit berumur 21-25 tahun yang berjumlah laki-laki 1 orang dan perempuan 1 orang, atau sekitar 2,5\% untuk laki-laki dan 2,5\% untuk perempuan dari total jumlah sampel yang ada.

Pada Tabel 3 dapat di lihat bahwa jumlah alat musik yang terbanyak adalah gitar akustik yaitu dimainkan oleh 11 orang atau sekitar 27,5\% dan jumlah alat musik paling sedikit adalah violin yang dimainkan oleh 5 orang atau sekitar 12,5\% dari total jumlah sampel yang ada.

Tabel 3. Distribusi frekuensi tekanan darah berdasarkan jenis alat musik

\begin{tabular}{ccccc}
\hline $\begin{array}{c}\text { Jenis } \\
\text { Alat } \\
\text { Musik }\end{array}$ & & & $\begin{array}{c}\text { Sebelum } \\
\text { Bermain } \\
\text { Musik }\end{array}$ & $\begin{array}{c}\text { Sesudah } \\
\text { Bermain } \\
\text { Musik }\end{array}$ \\
\cline { 3 - 5 } & n & Rerata TD & $\begin{array}{c}\text { Rerata TD } \\
\text { (mmHg) }\end{array}$ & (mmH) \\
\hline Keyboard & 8 & 20 & $116 / 75$ & $117 / 75$ \\
Piano & 7 & 17.5 & $111 / 70$ & $112 / 70$ \\
Violin & 5 & 12.5 & $118 / 74$ & $116 / 68$ \\
Gitar & 11 & 27.5 & $120 / 79$ & $118 / 78$ \\
Akustik & 9 & 22.5 & $115 / 75$ & $135 / 90$ \\
Drum & 9 & & & \\
\hline Total & 40 & 100 & & \\
\hline
\end{tabular}

Tabel 2. Distribusi frekuensi tekanan darah berdasarkan umur

\begin{tabular}{|c|c|c|c|c|c|c|c|c|c|c|}
\hline \multirow{2}{*}{$\begin{array}{l}\text { Umur } \\
\text { (Tahun) }\end{array}$} & \multicolumn{2}{|c|}{ Laki-Laki } & \multirow{2}{*}{$\begin{array}{c}\begin{array}{c}\text { Sebelum } \\
\text { Bermain } \\
\text { Musik }\end{array} \\
\text { Rerata TD } \\
\text { (mmHg) }\end{array}$} & \multirow{2}{*}{$\begin{array}{c}\begin{array}{c}\text { Sesudah } \\
\text { Bermain } \\
\text { Musik }\end{array} \\
\text { Rerata TD } \\
\text { (mmHg) } \\
\end{array}$} & \multicolumn{2}{|c|}{ Perempuan } & \multirow{2}{*}{$\begin{array}{c}\begin{array}{c}\text { Sebelum } \\
\text { Bermain } \\
\text { Musik }\end{array} \\
\text { Rerata TD } \\
\text { (mmHg) }\end{array}$} & \multirow{2}{*}{$\begin{array}{c}\text { Sesudah } \\
\text { Bermain } \\
\text { Musik } \\
\text { Rerata TD } \\
\text { (mmHg) } \\
\end{array}$} & \multicolumn{2}{|c|}{ Total } \\
\hline & $\mathbf{n}$ & $\%$ & & & $\mathbf{n}$ & $\%$ & & & $\mathbf{n}$ & $\%$ \\
\hline $10-15$ & 7 & 17.5 & $117 / 75$ & $124 / 80$ & 8 & 20 & $115 / 71$ & $116 / 70$ & 15 & 37.5 \\
\hline $16-20$ & 11 & 27.5 & $117 / 75$ & $122 / 80$ & 5 & 12.5 & $112 / 74$ & $116 / 76$ & 16 & 40 \\
\hline $21-25$ & 1 & 2.5 & $120 / 80$ & $120 / 70$ & 1 & 2.5 & $120 / 80$ & $120 / 80$ & 2 & 5 \\
\hline $26-30$ & 2 & 5 & $120 / 76$ & $130 / 83$ & 1 & 2.5 & $110 / 80$ & $110 / 80$ & 3 & 7.5 \\
\hline 31-35 & 4 & 10 & $123 / 80$ & 0 & 0 & 0 & $120 / 76$ & 0 & 4 & 10 \\
\hline Total & 25 & 62.5 & & & 15 & 37.5 & & & 40 & 100 \\
\hline
\end{tabular}


Dan terlihat bahwa tekanan darah meningkat pada pemain alat musik drum sebanyak 2 kali lipat dengan rerata sebelum bermain musik 115/75 mmHg dan sesudah bermain musik 135/90 mmHg. Sedangkan penurunan tekanan darah terjadi pada pemain alat musik violin (biola) dengan rerata sebelum bermain musik 118/74 $\mathrm{mmHg}$ dan sesudah bermain musik 116/68 mmHg.

\section{BAHASAN}

Berdasarkan hasil penelitian dapat diketahui karakteristik subjek penelitian meliputi: yang pertama Jenis Kelamin, berdasarkan Tabel 1 yang menjadi subjek penelitian pada penelitian ini paling banyak adalah laki-laki yang berjumlah 25 orang atau sekitar $62.5 \%$ dan perempuan sebanyak 15 orang atau sekitar 37.5\%. Dan umur yang paling banyak dalam mengikuti penelitian ini berumur 16-20 tahun (Tabel 2). Berdasarkan referensi di atas dapat diketahui bahwa berdasarkan jenis kelamin subjek penelitian, subjek dengan jenis kelamin perempuan mempunyai tekanan darah yang sedikit lebih rendah dibanding laki-laki, dan hal tersebut dijumpai dan terbukti pada penelitian yang telah dilakukan dimana ratarata terdapat perbedaan tekanan darah antara perempuan dan laki-laki. Hal ini sesuai dengan teori indu khurana (2006) yang menyatakan tentang perbedaan tekanan darah berbeda pada laki-laki dan perempuan. Hormone terstosteron dan estrogen turut berperan dalam peningkatan tekanan darah. Sebelum menopause tekanan darah perempuan lebih rendah dari pada pria seumurnya, tetapi setelah menopause tekanan darahnya lebih meningkat. ${ }^{8,10,11}$

Yang kedua Umur, seluruh populasi atau subjek penelitian yang dipakai sebagai sampel dalam penelitian ini berusia antara 10-35 tahun. Rata-rata umur subjek penelitian yang terbanyak 16-20 tahun. Berdasarkan Table 2, distribusi tekanan darah berdasarkan umur. Pengukuran tekanan darah pada umur 10-15 tahun, 1620 tahun, dan 26-30 tahun yang dilakukan sebelum dan sesudah bermian music terdapat hipertensi rigan. Sedangkan umur
10-15 tahun, 16-20 tahun, 26-30 tahun yang dilakukan sebelum dan sesudahbermain music terdapat normal tinggi, namun peningkatan tekanan darah yang terjadi pada umur 10-15 tahun, 16-20 tahun, dan 26-30 tahun masih dalam batas normal karena sesuai dengan aktifitas fisik yang dilakukan saat sebelum dan sesudah bermain alat musik (Tabel 2). Resiko untuk terkena hipertensi antara umur 30-50 tahun. Namun pada hasil penelitian ini diperoleh umur 1620 tahun lebih banyak terjadi peningkatan tekanan darah dari pada umur 30-35 tahun. Hal ini di karenakan jumlah subjek penelitian sebagian besar berada pada umur tersebut, sehingga distribusi frekuensi tekanan darah berdasarkan umur akan mengikuti kelompok umur subjek penelitian terbanyak. ${ }^{10}$ Tekanan darah akan cenderung tinggi bersama dengan peningkatan usia. Umumnya sistolik akan meningkat sejalan dengan peningkatan usia, sedangkan diastolik akan meningkat sampai usia 55 tahun. Semakin tua umur seseorang tekanan sistoliknya semakin tinggi. Berdasarkan referensi di atas dapat diketahui bahwa umur subjek penelitian masih dalam keadaan normal untuk peningkatan dan penurunan tekanan darah saat sebelum dan sesudah bermain musik. Selain itu peran pengaruh aktifitas fisiklah yang mempengaruhi peningkatan dan penurnan tekanan darah saat sedang bermain musik hingga menghasilkan kategori dari tekanan darah yang berbeda. ${ }^{6,8,10,11}$

Ketiga tekanan darah, yakni tekanan yang ditimbulkan pada dinding arteri. Tekanan puncak terjadi saat ventrikel berkontraksi dan disebut tekanan sistolik. Tekanan diastolik adalah tekanan terendah yang terjadi saat jantung beristirahat. Tekanan darah biasanya digambarkan sebagai rasio tekanan sistolik terhadap tekanan diastolik, dengan nilai dewasa normalnya berkisar dari 100/60 mmHg sampai 130/90 mmHg. Adapun distribusi frekuensi tekanan darah berdasarkan jenis alat musik, (Tabel 3) terlihat bahwa tekanan darah meningkat pada pemain musik drum sebanyak 2 kali lipat yakni sebelum bermain musik 115/75 mmHg dan sesudah bermain 
musik 135/90 mmHg. Sedangkan penurunan tekanan darah terjadi pada pemain alat musik biola (violin) dengan rerata sebelum bermain musik 118/74 mmHg dan sesudah bermain musik 116/68 mmHg. Tekanan darah bisa berubah setiap saat seiring dengan bertambahnya usia, waktu dan juga dipengaruhi oleh berbagai factor seperti lingkungan, aktifitas fisik, emosi, stress, dan lain-lain. Begitu juga dengan lokasi tempat sekolah musik yang terletak di lantai 2, maka hal ini menjadi faktor yang mempengaruhi perubahan tekanan darah saat pengambilan sampel sebelum bermain musik, sehingga terdapat beberapa sampel yang tekanan darahnya tidak sesuai dengan hasil normal. ${ }^{3,11}$

\section{SIMPULAN}

Berdasarkan hasil penelitian dan pembahasan gambaran tekanan darah terhadap pemain musik, dapat disimpulkan bahwa peningkatan tekanan darah terjadi pada saat dilakukan pengukuran sesudah bermain musik pada alat musik tertentu seperti drum didapat tekanan darah dengan kategori hipertensi ringan sebanyak 5 orang atau sekitar $12,5 \%$ dengan rerata tekanan darah 140/92 mmHg. Sedangkan penurunan tekanan darah terjadi pada saat dilakukan pengukuran sesudah bermain musik pada alat musik violin (biola) didapat tekanan darah dengan kategori optimal sebanyak 2 orang atau sekitar 5\% dengan rerata 110/60 mmHg.

\section{DAFTAR PUSTAKA}

1. Guyton AC. Fisiologi Manusia dan Mekanisme Penyakit (Edisi III). Jakarta: EGC, 1990; h.165-6.

2. Guyton and Hall. Fisiologi Kedokteran (Edisi ke-11). Jakarta: EGC; 2007.

3. Sherwood L, Fisiologi Manusia dari Sel ke Sistem (Edisi Kedua). Jakarta: EGC, 2008; h.304-6.

4. Gunawan L. Hipertensi Tekanan Darah Tinggi. Yogyakarta: Kanisius, 2001; h.1718.

5. Burns J, Labbe E, Williams K, McCall J. Perceived and Physiological Indicators of Relaxation: as different as Mozart and Alice in chains. Applied Psychophysiology and Biofeedback. 1999;24;3:197-198.

6. Djohan. Terapi Musik, Teori dan Aplikasi, Yogyakarta: Galang Press; 2006.

7. Djohan. Respons Emosi Musikal. Bandung: Lubuk Agung; 2010.

8. Campbell D. The Mozart Effect Tapping the Power of Music to Heal the Body, Strengthen the Mind, and Unlock the Creative of Spirit. Di terjemahkan oleh Drs. T. Hermaya. Jakarta: Gramedia Pustaka Utama, 2001; h.96-8.

9. Thompson H.A, Grocke D. Effects of Music Therapy on Anxiety in Patients who are Terminally ill. Journal of Falliative Medicine. 2008;11;4:582-590.

10. Khurana I. Textbook of Medical Physiology. 2006; p.336.

11. Aldridge D. Music, Communication and Medicine: discussion paper. Journal of the Royal Society of Medicine. 82;12:743-6 